\title{
The Foundation for Environmental Conservation: Auspices, Objectives, and Needs
}

The Foundation (FEC), which had started operating unofficially some years earlier, was finally established legally in 1975 at Grand-Saconnex, Geneva, Switzerland, as non-profit and tax-exempt by authority of the Council of State of the Republic and Canton of Geneva and perpetually under Swiss Federal Government surveillance by the Department of the Interior, Berne. Its viewpoint and emphasis are fully global and its activities as widely international as possible. Its headquarters are at 7 Chemin Taverney, 1218 Grand-Saconnex, Geneva, Switzerland (telephone [022] $982383 \& 982384)$.

\section{FOUNDERS AND GOVERNING BOARD}

The Founders were the International Union for Conservation of Nature and Natural Resources (IUCN), the World Wildlife Fund (now renamed World Wide Fund for Nature) International (WWF), both now situated at Gland, Switzerland, and Professor Dr Nicholas Polunin, of the above address. The Governing Board of the Foundation consists of the last-named for life and a representative each of IUCN and WWF, with powers to co-opt a very limited number of other members for periods of three years at a time (renewable for similar periods).

\section{OBJECTIVES (UPDATED)}

A. To undertake, in cooperation with appropriate individuals, organizations, and other groups, all possible activities to further the ends indicated in its title, and specifically:

B. To own and promote pertinent publications, in particular the international Journal Environmental Conservation, and to derive therefrom revenues to be used especially towards coverage of publication costs - in mind are certain other journals, possible supplements to the present one, and, ultimately, much-needed works of reference. The Foundation-sponsored, open-ended series of Environmental Monographs \& Symposia started publication in 1981, and a complementary series of shorter 'readers', entitled Cambridge Studies in Environmental Policy, will soon be coming into production: the latter at least will be paying a royalty to the Foundation;

C. To foster pertinent conferences, in particular the International Conferences on Environmental Future (ICEFs), and to sponsor the Baer-Huxley Memorial Lectures:

D. To organize specialist 'Workshops' etc. to deliberate and pronounce freely on urgent aspects of environmental despoliation or other causes for grave concern, e.g. the widespread die-back of trees and more general devegetation;

E. To encourage, and where possible promote, studies on environmental change, including ecobiome or ecosystem development and maintenance;

F. To institute through appropriate auspices, and thereafter continue to sponsor and promote, the World Campaign for The Biosphere, 1982-, whose functions are henceforth to be fostered primarily by the World Council For The Biosphere (see 6 below) and the affiliated International Society for Environmental Education; and

G. to accept and administer (under Swiss Federal surveillance by the Department of the Interior, Berne, and the authority of the Council of State of the Republic and Canton of Geneva), funds for the above purposes, including creation and bestowal of suitable awards for environmental achievement and allied enterprise.

\section{Adopted Projects, etc.}

\section{Environmental Conservation}

The Foundation having re-assumed financial responsibility for the printing and production of the Foundation's
Journal, and help from the United Nations Environment Programme and other sources having covered incidental needs of the Journal through 1986, funds will be required henceforth for its support in such matters as subventions for extra pages published beyond the standard 88 of text per issue and to pay for illustrations, proof corrections, and other incidental expenses which hitherto were largely contributed with his services by the President in his capacity as Editor but which mounting costs and taxes are making it increasingly difficult for him to support unaided. In addition, funds are desirable (1) to cover more editorial and incidental expenses, and (2) to increase the value of a prize or prizes for the best paper or papers published each year in Environmental Conservation.

\section{Office and Allied Expenses}

With ever-mounting costs and taxes (though the Foundation itself is non-profit and tax-exempt), and problems inter alia of currency exchange, it is becoming increasingly difficult to maintain the Secretariat privately, despite assistance from the Journal's Publisher and intermittent help from United Nations and other sources. Consequently funds are needed to help defray essential office etc. expenses-including those of two telephones and heavy postage, subscriptions, purchases of reference works and other equipment, extra pages in the Journal, useful reprints and entertaining, and necessary travel when sanctioned by the Board. In addition, some financing is now desired for payment of casual assistance, attendance at conferences and meetings, and reimbursement of services and taxes paid for the Secretariat.

\section{International Conferences on Environmental Future}

Whereas the President's family hopes to continue to refrain from reclaiming the amount still owing to him personally in respect of the 2nd ICEF (actually from the proceeds of the ad hoc sale of his arctic library to the Government of Canada), substantial sums will be needed to carry out any further ICEFs, though it is expected that the bulk of necessary financing will in general be contributed by or through the suitable host countries. The first ICEF in 1971 cost approximately $\$ 44,000$ (apart from relieving gifts and the generosity of the host Government of Finland) and the 2nd ICEF $c$. $\$ 65,000$ (including preparation and publication of the Proceedings in adequate detail, but apart from the help of the host Government of Iceland and various Icelandic services).

The 3rd ICEF is expected to take place in September 1987 and to be quite small, solely by invitation, and lasting only two days-hence less costly even than the first. The 4th ICEF, however, should be much larger again and held by 1989 ; it is likely to cost at least four times as much as the 2nd, in view of ever-rising prices and the need nowadays to pay the expenses of an increasing proportion of participants, and so the 'ideal' budget has been divided into six units of $\$ 50,000$ each, which are accordingly being sought - for accommodation, fares, administration, publicity and publication, honoraria to authors etc., and incidentals. These last include the Baer-Huxley Memorial Lecture and propitious workshops.

\section{Other Journals and Series of Books}

(a) Means are desired to encourage and help further needed journals through sponsorships, memberships, or grants, an example being Environmental Awareness, the organ of the Indian Society of Naturalists (INSONA), of which the President and his Wife are Patrons. Other instances include The Biosphere and the Bulletin of the Asian Society for Environmental Protection of which the President is a Life Member.

(b) Environmental Monographs \& Symposia: Means are desired to support special cases with a leading interna- 
tional Publisher, and to help the complementary Cambridge Studies in Environmental Policy series (likewise sponsored by the Foundation), consisting of highly authoritative 'readers' for environmental policymakers, politicians, and the enlightened public.

\section{World Education Concerning The Biosphere}

With the object of promoting world-wide knowledge of The Biosphere and appreciation of how humans are an integral part of it and utterly dependent on it, and yet are threatening it with their ever-increasing numbers and pressures on its finite resources, there were proposed in Environmental Conservation successively an 'International Year of the Biosphere' that was soon extended to 'The World Decade of The Biosphere, 1982-92' but then redesignated and subsequently declared as 'The World Campaign for The Biosphere, 1982-', which the Foundation initiated and continues to sponsor but which, as of early October 1983, was taken over by the Joint World Council For The Biosphere-International Society for Environmental Education - the former of which was founded primarily to foster the World Campaign for The Biosphere, while the latter became most closely associated with the North American Association for Environmental Education (NAEE), of which the President is a Life Member. The former joint body was commonly referred to by its acronym of WCB-ISEE and had a Joint Coordinating Committee (JCC); but after three years of trial this last was abandoned 'in the interests of simplicity for direct action' and WCB and ISEE effectively separated, though with the advising of ISEE a major responsibility of WCB, which has now come more fully under the aegis of the Foundation.

\section{The World Council For The Biosphere}

The origins of this body, henceforth to function as an important project of the Foundation, are explained in the last paragraph above, its main purpose being 'to protect the continued integrity of The Biosphere by serving as a select international forum for the analysis and appraisal of existing and foreseeable relationships between human population and economic development on one hand and, on the other, the totality of living and life-support systems of our planet which collectively constitute The Biosphere.' For subsidization of the general running and meetings of WCB, reimbursement of costs especially of its Executive Secretary, travel by its appointed officers and sanctioned maximum of 17 other Councillors, and satisfaction of various concomitant needs, an endowment of one million US dollars or Swiss francs is needed and being sought, as agreed by the Governing Board of the Foundation and approved in principle by both of the governmental supervisors.

\section{Research and Writing Projects}

(a) Various worthy research projects have been encouraged, with due publication of their results, but a budgetary item to help future ones financially would be welcomed. As a specific item it is thought that a project on Nature in a Concrete Jungle could be promoted with little special financing, at least in its early stages.

(b) Among writing and editing projects, in addition to the President's recent Ecosystem Theory and Application in the Environmental Monographs \& Symposia series, may be cited the need of a new edition of his Introduction to Plant Geography and Some Related Sciences which, though published in 1960 and now badly outdated, is still being widely used and even translated (currently into Indonesian). The new edition should include additional sections on pollution effects and ecology, plant conservation, introductions and their effects, competition, continental drift, and the role of plants in environmental conservation - for all of which, and widespread updating, special collaboration widd 3 besceded 88 Published online by Cambridge University Press

\section{Other Desiderata}

(a) Feasibility study of a proposed top-level World Academy of Environmentalists (now that the educational etc. aspects are being furthered especially by the bodies mentioned in No. 5 above).

(b) Compilation when and how practicable of an International Who's Who in the Environmental/Conservational Movement.

(c) Practical proposal of a World Wilderness Alliance.

(d) Investigation of the practicability of establishing an international environmental centre and/or "conservation campus'-such as was discussed at the 12th AGM of the Foundation and for which an ad hoc feasibility study would seem urgent.

(e) Endowment of the Baer-Huxley Memorial Lectures on topics of contemporary environmental concern, normally given in connection with International Conferences on Environmental Future (see 3 above).

(f) Endowment of a prize or prizes for the best paper or papers published each year in Environmental Conservation, and ultimately of a major award or awards for environmental achievement and enterprise. Based on the findings of a small secret Selection Committee, the first 'best paper' prize or prizes will be awarded early in 1987 but will be modest as coming substantially from the Foundation's savings from only giving out free offprints when requested on the green ordering forms accompanying proofs.

(g) Encouragement of a Canadian initiative for 'The Arctic as a Regional Sea'.

(h) Funds to convene working groups of leading speciaiists to pronounce quite freely on major environmental threats and advise WCB (see 5 and 6 above) concomitantly. An endowment of US $\$ 7$ millions or SFr. 10 millions would suffice for this and meanwhile satisfy some of the above needs from income.

Further projects are under consideration, including urgent research proposals, a major World Heritage Series of volumes, establishment of a biennial award for demonstrated environmental concern and concomitant action by a multinational corporation, and fostering the establishment of associated foundations etc. in other parts of the world. With the demise of the Pahlavi Prize and the opening of the Tyler Prize to wider concerns, a major award for environmental leadership is an urgent need-if possible on a par with the Nobel Peace Prize (for which, incidentally, the nomination of leading environmentalists seems particularly desirable).

\section{OPERATION AND NEEDS}

With the running costs already contributed, and in the absence of any institutional overheads and taxes other than those that continue to be paid privately, the Foundation constitutes what has been called a uniquely economic vehicle for support of the environmental/conservational movement-whether generally or through specific projects which can be put in train as soon as or soon after funds become available. Contributions are warmly welcomed and individually acknowledged, and can be received in any negotiable currency by cheque made out to the Foundation for Environmental Conservation, c/o Banque Populaire Suisse, 1 Quai des Bergues, 1211 Geneva, Switzerland, or sent to the Foundation's address ending the opening paragraph of this notice. [Plans for recognizing special services or substantial donations to the Foundation by the award of an engraved certificate designed by a renowned draughtsman have been shelved with the demise of the draughtsman and in view of the urgent need of all available funds for more pressing purposes, though donors are requested to identify themselves clearly unless anonymity is desired.]

Nicholas Polunin, President

The Foundation for Environmental Conservation (updated version following its 12th Annual General Meeting. held on 27 Fehruarv 1987). 